\title{
Agro-Morphologies and Physicochemical Properties of Flower Bud, Stem and Leaf Oils in Two Clove Varieties \\ (Syzygium aromaticum L. Merr. and Perry.) Originated from Ambon Island
}

\author{
Hariyadi, Asri Subkhan Mahulette ${ }^{1^{*}}$, Sudirman Yahya², \\ and Ade Wachjar ${ }^{2}$
}

\begin{abstract}
${ }^{1}$ Agrotechnology Study Program, Faculty of Agriculture, Pattimura University, Unpatti Poka Campus, Ambon 97234

${ }^{2}$ Department of Agronomy and Horticulture, Faculty of Agriculture, IPB University, Bogor 16680

*Corresponding author.E-mail: mahulette_07@yahoo.co.id https://doi.org/10.12982/CMUJNS.2020.0034
\end{abstract}

Received: September 30, 2019

Revised: December 29, 2019

Accepted: January 6, 2020

\begin{abstract}
The cloves of Tuni and Zanzibar varieties from Ambon Island have morphological differences that affect the production and quality of the clove oil produced. This study aimed to evaluate the characteristics of the agromorphology and physicochemical properties of clove oil of the two varieties. The standard color determination was performed visually, specific gravity was using pycnometer, refractive index using a refractometer, and $70 \%$ ethanol solubility using silver nitrate $0.1 \mathrm{~N}$. Total eugenol was determined using $4 \%$ Potassium Hydroxide (KOH) solution, while $\beta$-caryophyllene was analyzed using gas chromatography technique (GC) Agilent Technologies 6890N. The study of morphological aspect and essential oils characteristics of two clove varieties demonstrated large variability of this species grown in Ambon Island. Results of this study revealed that the highest oil content was found in bud oil of Zanzibar variety, while the lowest was in leaf oil of Tuni variety. In addition, Zanzibar variety tends to contain higher volatile oil content than Tuni. Furthermore, it was found that Tuni variety contained total eugenol in flower bud oil, stem, and leaf slightly higher than Zanzibar variety, with about $84 \%$, $98 \%$, and $78 \%$. This finding implies that the whole clove oil from the different morphological parts of the two varieties fulfilled the standard of clove oil, although there was a slight different of a higher $\beta$-caryophyllene content. The PCA results showed that the oil content in the flower bud section was high. The increase in flower weight and oil content was not always followed by an increase in eugenol content.
\end{abstract}

Keywords: Aroma, Essential oil, Eugenol, Volatile compund. 


\section{INTRODUCTION}

Cloves (Syzygium aromaticum L. Merr. and Perry.) are classified as essential oils producing plants from the family of Myrtaceae (Milind and Deepa, 2011; Rathinam and Viswanathan, 2018; Alfian et al., 2019; Mahulette et al., 2019a). The species of this plant is native to Indonesia from the Maluku Islands, also known as the Spice Island (Milind and Deepa, 2011; Mahulette et al., 2019b). As part of the Maluku archipelago, clove plants are often found in Ambon Island, which is in Maluku Province because it is widely cultivated by farmers. Clove in Ambon Island is one of the primary plantation commodities and a source of income for farmers who live from the plantation sector. Cloves in Ambon Island are dominated by Tuni variety which has been released by the government as a superior variety (Ministry of Agriculture, 2013). In addition to this variety, there are also other aromatic clove varieties, including Zanzibar. The two types of cloves are part of the clove germplasm resources in the area of Maluku Province. Tuni and Zanzibar varieties have similarities in terms of agro-morphology, but there are several characteristics that distinguish the two varieties. The difference in the characteristics of the agro-morphology indicates the difference in essential components contained in the two varieties.

Tuni and Zanzibar clove varieties are equally classified as aromatic cloves which are considered to have a superior quality. The distinctive aroma of both aromatic cloves provides opportunities for use in the form of essential oils. So far, the use of cloves in the distribution area in Maluku Province is only in the form of dried clove flowers, and the utilization in the form of essential oils is still limited (Mahulette et al., 2019c), even though the use of cloves in the form of essential oils is more profitable compared to the utilization in the form of dried clove flowers (Milind and Deepa, 2011).

Clove oil can be extracted from the flower (bud oil), flower stalks (stem oil), and leaves (leaf oil) with the main component in the form of eugenol then followed by eugenyl acetate, caryophyllene and other minor components (Alma et al., 2007; Sohilait, 2015; Riyanto et al., 2016; Nejad et al., 2017; Uddin et al., 2017). Differences in the production and composition of essential oils are strongly influenced by plant type and growth environment (Figueiredo et al., 2008; Amini et al., 2016). Sources of plant material and the environment influence the chemical composition of essential oils because they are related to the plant adaptation (Maksimovic' et al., 2007; Figueiredo et al., 2008).

The demand for Indonesian clove oil in the world market continues to increase (Daryono, 2015) because it is widely used in medication and aromatherapy due to its biological activities and uses (Jentzsch et al., 2017). As a major producer of clove oil in the world, however, meeting the needs of eugenol in various industries in Indonesia is still being fulfilled through imports because Indonesia's clove oil exports are mainly still in the form of raw materials 
(Towaha, 2012). The high demand for clove oil on the world market has encouraged the use of clove germplasm resources to produce quality clove oil so that it can compete globally. Physico-chemical parameters in the standard quality of clove oil include color, specific gravity, refractive index, solubility in alcohol, total eugenol, and $\beta$-caryophyllene. These parameters are determined by many factors including the type of plant material and parts of the plant used (Figueiredo et al., 2008), in addition to other factors such as the quality of raw materials and distillation methods (Safrudin et al., 2015).

This study aimed to reveal the characteristics of agro-morphology and physicochemical properties of clove oil from Tuni and Zanzibar varieties from Ambon Island from the distillation of flowers, flower stalks, and leaves. The parameters were then analyzed to investigate the relation to some of the characteristics of plant agro-morphology. This research is important to describe the characteristics of agro-morphology and the potential physicochemical properties of the oil from the two varieties for the development of clove oil agroindustry.

\section{MATERIALS AND METHODS}

\section{Plant materials preparation}

Clove plants of Tuni and Zanzibar varieties from Ambon Island were chosen from Liliboy Village, Leihitu Barat District, Central Maluku Regency, Maluku Province, Indonesia $\left(03^{\circ} 44^{\prime} 46.8^{\prime \prime} \mathrm{E}-128^{\circ} 01^{\prime} 10.1^{\prime \prime} \mathrm{S}\right.$, at an elevation of $110.2 \mathrm{~m}$ ), in September 2018. Plant materials from each variety consisted of 10 trees that were previously characterized before being sampled for distillation. Criteria of selected plants were healthy and were more than 15 years old. The agro-morphological characterization of the two varieties of cloves referred to the modified IPGRI (1980). Measurement of the length of the morphological parts was performed using a measuring ruler, while the diameter using a vernier caliper. Determination of the color of plant morphology was performed using the RHS color chart 2015. The parts of the plants to be distilled were composited from each variety. Plant materials consisted of flowers, flower stalks, and leaves. Handling of clove samples is carried out following the procedure from Ketaren (1985). Flowers and flower stalks were dried using sunlight for 3-4 days during sunny weather conditions up to $14 \%$ moisture content, while the leaves were withered using a ventilated drying oven at $30{ }^{\circ} \mathrm{C}$ for an hour so that the water content decreased to $10-15 \%$ before distillation.

\section{Clove oil distillation}

Distillation and analysis of physicochemical properties were conducted at the Spice and Medicinal Crops Research Institute (BALITTRO), Bogor, Indonesia. The sample distillation was carried out using the steam-hydro distillation method at $100{ }^{\circ} \mathrm{C}$ using an essential oil distillation equipment designed by the Spice and Medicinal Crops Research Institute (BALITTRO), 
Bogor, Indonesia. The essential oil distillation equipment was divided into 2 parts separated by a filter screen. The bottom is the water that will be evaporated and the top is where to put the sample. The sample handling and distillation methods follow the procedure from Ketaren (1985). Distillation time of flowers, flower stalks and leaves is carried out for 6-10 hours until there was no oil dripping. Samples from each variety consisted of $1 \mathrm{~kg}$ of flowers, $2 \mathrm{~kg}$ of flower stalks, and $3 \mathrm{~kg}$ of leaves. Samples of flower stalks and leaves were directly distilled, but flower sample was ground and filtered by $0.5 \mathrm{~cm}^{2}$ size before distillation. The distillation process was carried out directly on each sample from the two varieties separately. After the oil was obtained, $2 \%$ of $\mathrm{Na}_{2} \mathrm{SO}_{4}$ was added to the distillation oil then it was stored in a dark bottle before the analysis of physicochemical properties.

\section{Analysis of physicochemical properties of clove oil}

Procedure for analyzing the physicochemical properties of clove oil was based on SNI 06-2387-2006. The analysis included color, specific gravity, refractive index, solubility in alcohol, total eugenol, and $\beta$-caryophyllene. Color determination was done visually using $10 \mathrm{ml}$ of clove oil in a $15 \times 20 \mathrm{ml}$ test tube. The oil color was then compared to the standard RHS color chart 2015. Determination of density was carried out by gravimetric method using a pycnometer at $20{ }^{\circ} \mathrm{C}$, while the refractive index was measured by using a refractometer at $20^{\circ} \mathrm{C}$. Determination of solubility in $70 \%$ ethanol was carried out by volumetric method using solution for turbidity comparison in the form of silver nitrate $0.1 \mathrm{~N}$. The determination of total eugenol was carried out using cassia flask and a $4 \%$ Potassium Hydroxide $(\mathrm{KOH})$ solution. The concentration of $\beta$-caryophyllene was determined using the gas chromatography (GC) technique (Agilent Technologies 6890N), with the condition of the equipment: the gas carrier in the form of nitrogen, flow rate of $30 \mathrm{ml} \mathrm{minute}^{-1}$, detector in the form of flame ionization detector (FID) with detector temperature of $250{ }^{\circ} \mathrm{C}$, hydrogen flow speed of $30 \mathrm{ml}$ minute ${ }^{-1}$ and gas flow rate of $300 \mathrm{ml} \mathrm{minute}^{-1}$, injector temperature of $200{ }^{\circ} \mathrm{C}$. The temperatures of the column used were: the initial temperature $80{ }^{\circ} \mathrm{C}$, the final temperature $200^{\circ} \mathrm{C}$, the temperature rise was $5{ }^{\circ} \mathrm{C}$ minute ${ }^{-1}$, the volume of sample was 0.1 microliter, and the paper speed was $0.5 \mathrm{~cm}$ minute $^{-1}$.

\section{Data analysis}

Analysis of the morphological characteristics, oil content, and physicochemical properties of clove oil of Tuni and Zanzibar varieties were carried out descriptively. The physicochemical properties of clove oil from flowers, flower stalks, and leaves were compared with the Indonesian National Standard (SNI): 06-4267-1996 for clove flower bud oil, SNI: 06-4374-1996 for clove stem oil, and SNI : 06-2387-2006 for clove leaf oil (BSN, 1996a, 1996b, 
2006), as well as with International Standard (ISO) 3141: 1997 (E) and Food Chemical Codex Edition IV. Principle Component Analysis (PCA) to investigate.

\section{RESULTS}

\section{The Agro-morphological characteristics of Tuni and Zanzibar clove varieties}

Tuni and Zanzibar clove varieties can be distinguished based on morphology of leaves, flowers, fruits, and seeds. The morphology of the two varieties of cloves is presented in Figure 1. Differences in morphological characters between the two varieties are shown in Table 1. Morphological observations showed that the cloves of Tuni and Zanzibar varieties have eliptical leaves with deep yellowish green color (141B), but different on top color. Clove of Tuni variety has moderate red colored shoots (179D), while Zanzibar variety has moderate red colored shoots (179B).

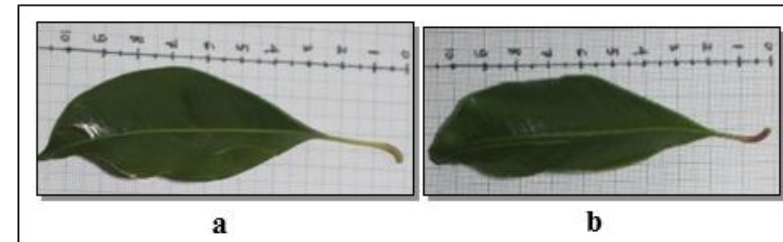

(A)

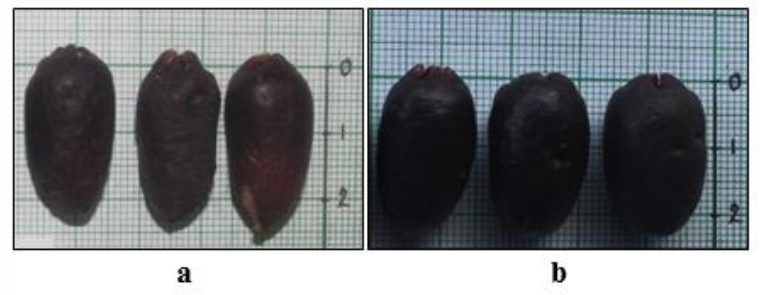

(C)

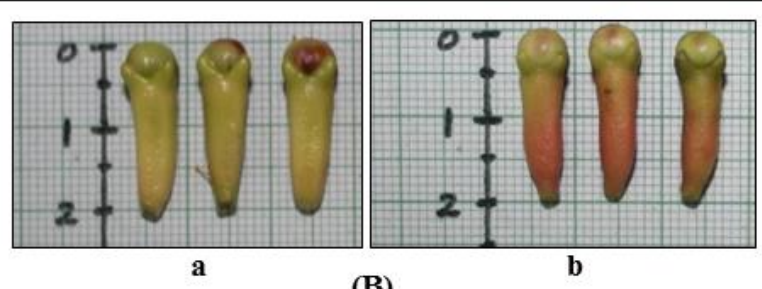

(B)

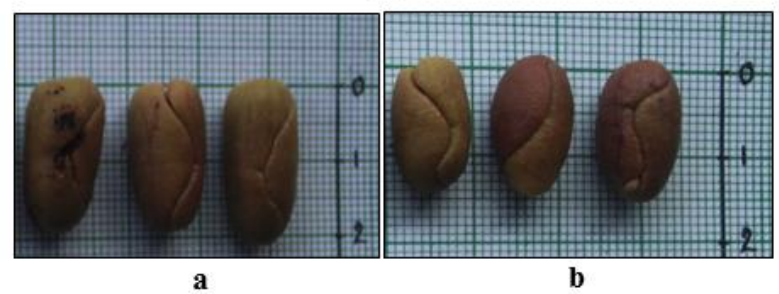

(D)

Figure 1. Morphology of leaves (A), flowers (B), fruits (C), and seeds (D); Tuni variety (a), Zanzibar variety (b).

Table 1. Agro-morphological characteristics of Tuni and Zanzibar clove varieties.

\begin{tabular}{lllcccc}
\hline Variety & Morphology & Shape & $\begin{array}{c}\text { Length } \\
(\mathbf{c m})\end{array}$ & $\begin{array}{c}\text { Width } \\
(\mathbf{c m})\end{array}$ & $\begin{array}{c}\text { Area } \\
\left(\mathbf{c m}^{\mathbf{2}}\right)\end{array}$ & $\begin{array}{c}\text { Weight } \\
\left(\mathbf{g}^{\mathbf{1}}\right)\end{array}$ \\
\hline Tuni & Leaf & Ellipse & $8.89 \pm 0.44$ & $4.05 \pm 0.42$ & $27.10 \pm 2.94$ & - \\
& Flower bud & Funnel & $1.95 \pm 0.15$ & $0.49 \pm 0.03$ & - & $0.37 \pm 0.03$ \\
& Stalks & Long & $5.05 \pm 0.20$ & - & & $1.42 \pm 0.45$ \\
& Fruit & Cone & $2.61 \pm 017$ & $1.31 \pm 010$ & - & $2.76 \pm 0.49$ \\
& Seed & Cone & $1.94 \pm 0.10$ & $0.92 \pm 0.06$ & - & $1.14 \pm 0.18$ \\
\hline Zanzibar & Leaf & Ellipse & $8.19 \pm 0.65$ & $3.33 \pm 0.39$ & $20.39 \pm 4.54$ & - \\
& Flower bud & Funnel & $1.89 \pm 0.09$ & $0.50 \pm 0.01$ & - & $0.38 \pm 0.02$ \\
& Stalks & Long & $4.95 \pm 0.80$ & - & - & $2.15 \pm 0.99$ \\
& Fruit & Cone & $2.18 \pm 0.10$ & $1.34 \pm 0.10$ & - & $2.51 \pm 0.32$ \\
& Seed & Cone & $1.47 \pm 0.09$ & $0.73 \pm 0.19$ & - & $0.62 \pm 0.12$ \\
\hline
\end{tabular}


Clove of Tuni variety has leaves with size slightly larger than those of Zanzibar variety. Clove of Tuni variety has leaves with an average length of $8.89 \mathrm{~cm}$ and a width of $4.05 \mathrm{~cm}$, while those of the Zanzibar variety has an average leaf length of slightly shorter $(8.19 \mathrm{~cm})$ and a width of $3.33 \mathrm{~cm}$. Likewise with the flower characters, the clove of Tuni variety has an average flower length of $1.95 \mathrm{~cm}$, a diameter of $0.49 \mathrm{~cm}$, and a weight of $0.37 \mathrm{~g}$, while the clove of the Zanzibar variety has an average flower length of $1.89 \mathrm{~cm}$, a diameter of $0.50 \mathrm{~cm}$, and a weight of $0.38 \mathrm{~g}$. The significant difference of the two varieties was in the color of the flower. The flower bud color of the Tuni clove variety was pale greenish yellow (2D), while the Zanzibar variety was strong pink (49A). Tuni clove has a longer and heavier fruit but smaller fruit diameter compared to Zanzibar variety. Tuni variety has an average fruit length of $2.61 \mathrm{~cm}$, width of $1.31 \mathrm{~cm}$, and weight of $2.76 \mathrm{~g}$; while the Zanzibar variety has fruit with an average length of $2.18 \mathrm{~cm}$, diameter of $1.34 \mathrm{~cm}$, and weight $2.51 \mathrm{~g}$. The fruit forms of the two varieties were conical and dark purple (79A). The Tuni clove variety has seeds with an average length, diameter, and weight greater compared to Zanzibar variety. Tuni clove variety has seeds with an average length of $1.94 \mathrm{~cm}$, diameter of $0.92 \mathrm{~cm}$, and weight of $1.14 \mathrm{~g}$, while the clove of Zanzibar variety has seeds with an average length of $1.47 \mathrm{~cm}$, diameter of $0.73 \mathrm{~cm}$, and weight of $0.62 \mathrm{~g}$. The shape and color of the seeds of the two varieties were the same, which are conic in shape with light purple (75B) seed color.

\section{Oil content}

Clove oil from Tuni and Zanzibar varieties was originated from the flowers (bud oil), flower stalks (stem oil), and leaves (leaf oil). The distillation method used to produce the oil was steam-hydrodistillation for 6 hours. Figure 2 shows the results of oil and water content of Tuni and Zanzibar varieties.

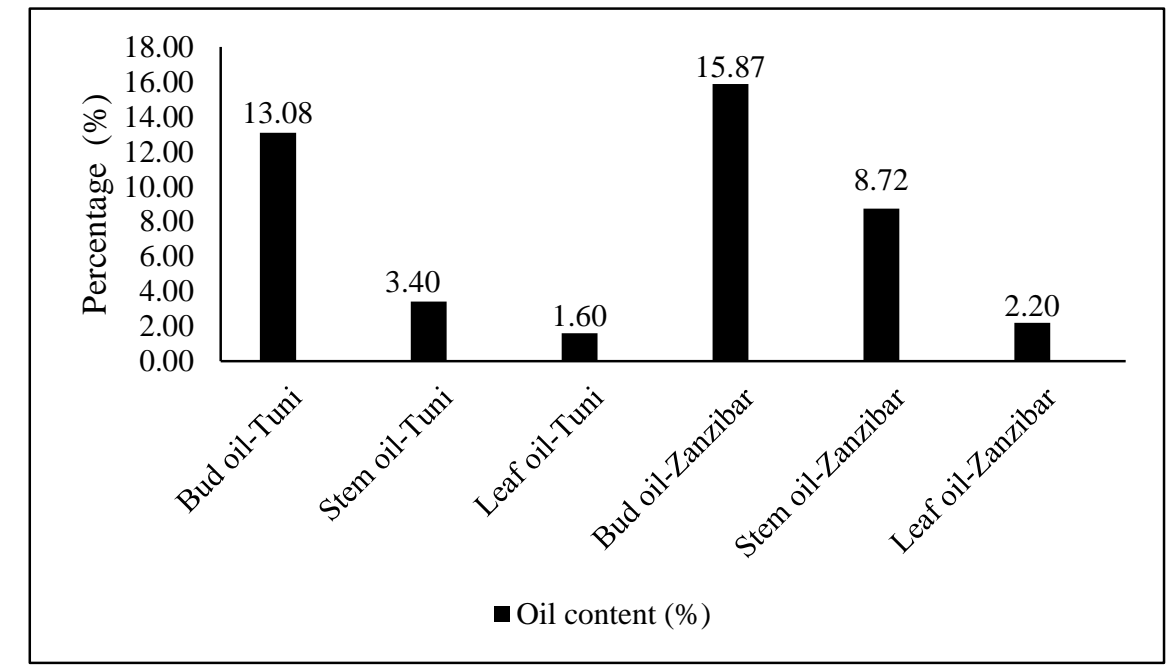

Figure 2. Clove oil contents of Tuni and Zanzibar varieties from parts of flowers (bud oil), stalks (stem oil), and leaves (leaf oil). 
The results showed that oil contents obtained from the Tuni cloves from flowers, stalks, and leaves were 13.08; 3.4; and 1.6\%, respectively. Meanwhile, the distillation of Zanzibar variety of clove oil from flowers, stalks, and leaves produced $15.87,8.72 \%$, and $2.2 \%$, respectively. The oil content was obtained at various levels of material water content, where the highest water content of material was found in leaf sample materials from both Tuni and Zanzibar varieties, which were $30.16 \%$ and $28.54 \%$, respectively. Meanwhile, the lowest water content was found in flower and stalk. The oil in Zanzibar variety was slightly higher than the oil content in the Tuni variety in all distilled parts. In addition, the results showed that the order of oil contents from the largest to the smallest in both varieties was found in the flower, stalk, and leaf sections, respectively.

\section{Oil color}

The visual results of clove oils from Tuni and Zanzibar varieties are presented in Figure 3. The determination of the physical color of clove oils of the two varieties was determined based on the color standard of 2015 RHS color chart (Table 2).
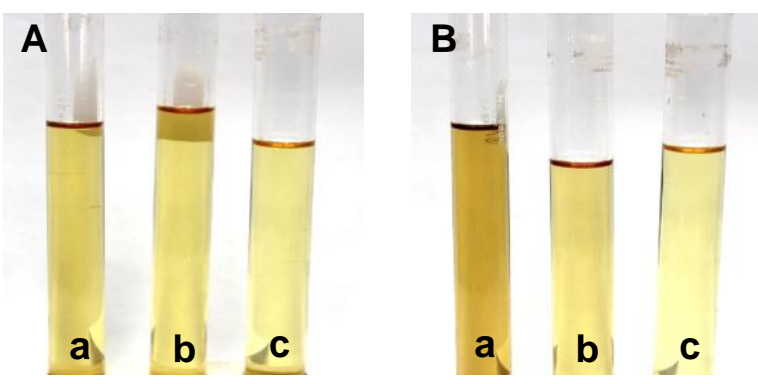

Figure 3. Color characteristics of clove oils. (A) Tuni variety, (B) Zanzibar variety; (a) bud oil; (b) stem oil; (c) leaf oil.

Visually, the physical color of clove oil from Tuni and Zanzibar varieties from the distillation of parts of flowers, flower stalks, and leaves was in the range of yellow to dark brown. The physical color of oil is visually classified as normal because it was in the standard range of clove oil. Based on the color standard on the 2015 RHS color chart showed that the overall color of flower oil, flower stalks and clove leaves of the Tuni variety were included in the yellow group color group, which are brilliant yellow (7A), brilliant greenish yellow (7C), and light greenish yellow (8C). Whereas for the Zanzibar variety, the flower oil belongs to the grayed orange group color group namely orange brown (N1671B), while flower stalk oil and leaf oil belong to the color group yellow group, which are brilliant yellow (7B) and light greenish yellow (8C). 
Table 2. Color standards of clove oils in Tuni and Zanzibar varieties.

\begin{tabular}{llll}
\hline Clove & & Tuni & Zanzibar \\
\hline \multirow{3}{*}{${ }^{1}$ Bud oil } & Code & 7A & N1671B \\
& Color & Brilliant yellow & Brownish orange \\
& Color group & Yellow group & Grayed orange group \\
\hline \multirow{2}{*}{ Stem oil } & Code & $7 \mathrm{C}$ & $7 \mathrm{~B}$ \\
& Color & Brilliant Greenish yellow & Brilliant yellow \\
& Color group & Yellow group & Yellow group \\
\hline \multirow{2}{*}{ Code } & 8C & 8C \\
& Color & Light greenish yellow & Light greenish yellow \\
& Color group & Yellow group & Yellow group \\
\hline \multirow{2}{*}{ SNI } & & Yellow to dark brown & Yellow to dark brown \\
& & (visual method) & (visual method ) \\
\hline
\end{tabular}

Note: ${ }^{1}$ Bud oil $=$ oil distilled from the flowers, ${ }^{2}$ Stem oil $=$ oil distilled from flower stalks, ${ }^{3}$ Leaf oil $=$ oil distilled from leaves. Data obtained from the distillation of Tuni and Zanzibar varieties from Ambon Island, which took place in September 2018, according to the 2015 RHS color chart SNI (indonesian national standart).

\section{Physico-chemical properties of oil}

Parameters in standardizing clove oil include parameters of specific gravity, refractive index, solubility in ethanol, total eugenol and $\beta$-caryophyllene (Table 3). The results of the analysis of physico-chemical properties of clove oil in Tuni and Zanzibar varieties in this study were standardized based on Indonesian National Standardization (SNI): 06-4267-1996 for clove flower oil, SNI: 06-4374-1996 for clove stem oil, and SNI: 06-2387-2006 for clove leaf oil (BSN, 1996a, 1996b, 2006), International Standard (ISO) 3141:1997(E) and Food Chemical Codex Edition IV (Table 4). The results of physicochemical analysis show that the two varieties had specific gravity, refractive index, solubility in $70 \%$ ethanol, and total eugenol which is within the standard range of clove oils, except for the content of $\beta$-caryophyllene from several clove oils of both varieties. Tuni clove oil at a temperature of $20^{\circ} \mathrm{C}$ had a specific gravity of $1.0443 \mathrm{~g} \mathrm{ml}^{-1}$ in bud oil, $1.0541 \mathrm{~g} \mathrm{ml}^{-1}$ in stem oil, and $1.0323 \mathrm{~g} \mathrm{ml}^{-1}$ in leaf oil. Tuni clove bud oil had a refractive index of 1.5350 at a temperature of $20^{\circ} \mathrm{C}, 1.5350 \mathrm{in}$ stem oil, and 1.5286 in leaf oil. Overall Tuni clove oil achieved $70 \%$ ethanol-soluble properties (1:2). In addition, the Tuni clove variety had the highest levels of eugenol found in stem oil (98\%) and bud oil (84\%) but were slightly lower in leaf oil (78\%).

The same standard was also achieved by Zanzibar variety. Clove oil of Zanzibar variety at a temperature of $20^{\circ} \mathrm{C}$ had a specific gravity of $1.0327 \mathrm{~g} \mathrm{ml}^{-1}$ in bud oil, $1.0382 \mathrm{~g} \mathrm{ml}^{-1}$ in stem oil, and $1.0372 \mathrm{~g} \mathrm{ml}^{-1}$ in leaf oil. Clove bud oil of Zanzibar variety had an index of refraction of 1.5263 at a temperature of $20^{\circ} \mathrm{C}$, 1.5317 in stem oil, and 1.5299 in leaf oil. The whole Zanzibar variety clove oil also achieved $70 \%$ ethanol solubility $(1: 2)$. In addition, Zanzibar variety had a high eugenol content in stem oil and leaf oil (each of 82\%), but it was slightly lower in bud oil (76\%). The results obtained from both Tuni and Zanzibar 
varieties showed that the eugenol contained in both varieties was quite high because the varieties were in a group of aromatic cloves. For the $\beta$-caryophyllene parameter, the Tuni clove variety contained $\beta$-caryophyllene which is still in the standardized range of $12.68 \%$ in bud oil and $6.99 \%$ in stem oil. The $\beta$-caryophyllene level of clove leaf oil of Tuni variety is slightly higher which was $20.93 \%$. In Zanzibar clove variety, the levels of $\beta$-caryophyllene meet the standard of stem oil which was $15.38 \%$, but it as slightly higher in bud oil and leaf oil, which were $19.03 \%$ and $18.26 \%$, respectively. The standard $\beta$-caryophyllene required in the standardization of clove oil is not more than $17 \%$.

Table 3. Physicochemical properties of Tuni and Zanzibar varieties' clove oils.

\begin{tabular}{|c|c|c|c|c|c|c|}
\hline Clove & Paremeter & $\begin{array}{l}\text { Specific } \\
\text { gravity } \\
\left(20^{\circ}\right) \\
(\mathrm{g} \mathrm{ml}-1)\end{array}$ & $\begin{array}{l}\text { Refractive } \\
\text { index }\left(20^{\circ}\right)\end{array}$ & $\begin{array}{l}\text { 70\% ethanol } \\
\text { solubility }\end{array}$ & $\begin{array}{l}\text { Total } \\
\text { Eugenol } \\
(\%)\end{array}$ & $\begin{array}{l}\beta- \\
\text { caryophyllene } \\
(\%)\end{array}$ \\
\hline \multirow[t]{3}{*}{ Tuni } & ${ }^{1}$ Bud oil & 10.443 & 1.5350 & $1: 2$ (soluble) & 84 & 12.68 \\
\hline & ${ }^{2}$ Stem oil & 10.541 & 1.5350 & $1: 2$ (soluble) & 98 & 6.88 \\
\hline & ${ }^{3}$ Leaf oil & 10.323 & 1.5286 & $1: 2$ (soluble) & 78 & 20.93 \\
\hline \multirow[t]{3}{*}{ Zanzibar } & ${ }^{1}$ Bud oil & 10.327 & 1.5263 & $1: 2$ (soluble) & 76 & 19.03 \\
\hline & ${ }^{2}$ Stem oil & 10.382 & 1.5317 & $1: 2$ (soluble) & 82 & 15.38 \\
\hline & ${ }^{3}$ Leaf oil & 10.372 & 1.5299 & $1: 2$ (soluble) & 82 & 18.26 \\
\hline \multicolumn{2}{|c|}{ Testing Method } & Gravimetry & Refractometry & Volumetry & Cassia & $\mathrm{GC}$ \\
\hline
\end{tabular}

Note: ${ }^{1}$ Bud oil $=$ oil distilled from the flowers, ${ }^{2}$ Stem oil $=$ oil distilled from flower stalks, ${ }^{3}$ Leaf oil $=$ oil distilled from leaves.

Table 4. Clove oil standards (Syzygium aromaticum (L.) Merr. \& L. M. Perry.)

\begin{tabular}{|c|c|c|c|c|}
\hline Parameters & $\begin{array}{l}{ }^{1} \text { SNI : 06- } \\
4267-1996\end{array}$ & $\begin{array}{l}{ }^{2} \mathrm{SNI}: 06- \\
4374-1996\end{array}$ & $\begin{array}{l}{ }^{3} \mathrm{SNI}: 06- \\
\text { 2387-2006 }\end{array}$ & $\begin{array}{c}\text { ISO: } \\
\text { 3141:1997(E) } \\
\text { and Food } \\
\text { Chemical Codex } \\
\text { Edition IV. } \\
\end{array}$ \\
\hline $\begin{array}{l}\text { Specific gravity }\left(20^{\circ}\right) \\
\left(\mathrm{g} \mathrm{ml}^{-1}\right)\end{array}$ & $1.04-1.07$ & $1.03-1.06$ & $1.03-1.05$ & $1.04-1.05$ \\
\hline Refractive index $\left(20^{\circ}\right)$ & $1.53-1.54$ & $1.510-1.52$ & $1.53-1.536$ & $1.53-1.53$ \\
\hline $70 \%$ ethanol solubility & $1: 2$ Clear & $1: 2$ Clear & $1: 2$ Clear & $1: 2$ Clear \\
\hline Total Eugenol (\%) & $80-95 \%$ & $78-95 \%$ & Min 78\% & $80-82 \%$ \\
\hline$\beta$-caryophyllene (\%) & - & - & $\operatorname{Max} 17 \%$ & $4-17 \%$ \\
\hline
\end{tabular}

Note: ${ }^{1}$ SNI: 06-4267-1996=SNI for clove bud oil, ${ }^{2}$ SNI:06-4374-1996=SNI for clove stem oil, ${ }^{3}$ SNI : 06-23872006=SNI for clove leaf oil. 


\section{Principle Component Analysis (PCA)}

The relationship of clove oil of Tuni and Zanzibar varieties with plant agromorphologies was analyzed using the Principle Component Analysis (PCA) (Figure 4). The parameters of clove oil that were correlated are in the form of oil content and eugenol levels from flowers, flower stalks, and leaves in both varieties. The morphological parameters of the plant were flower weight, flower stalk weight, and leaf area.

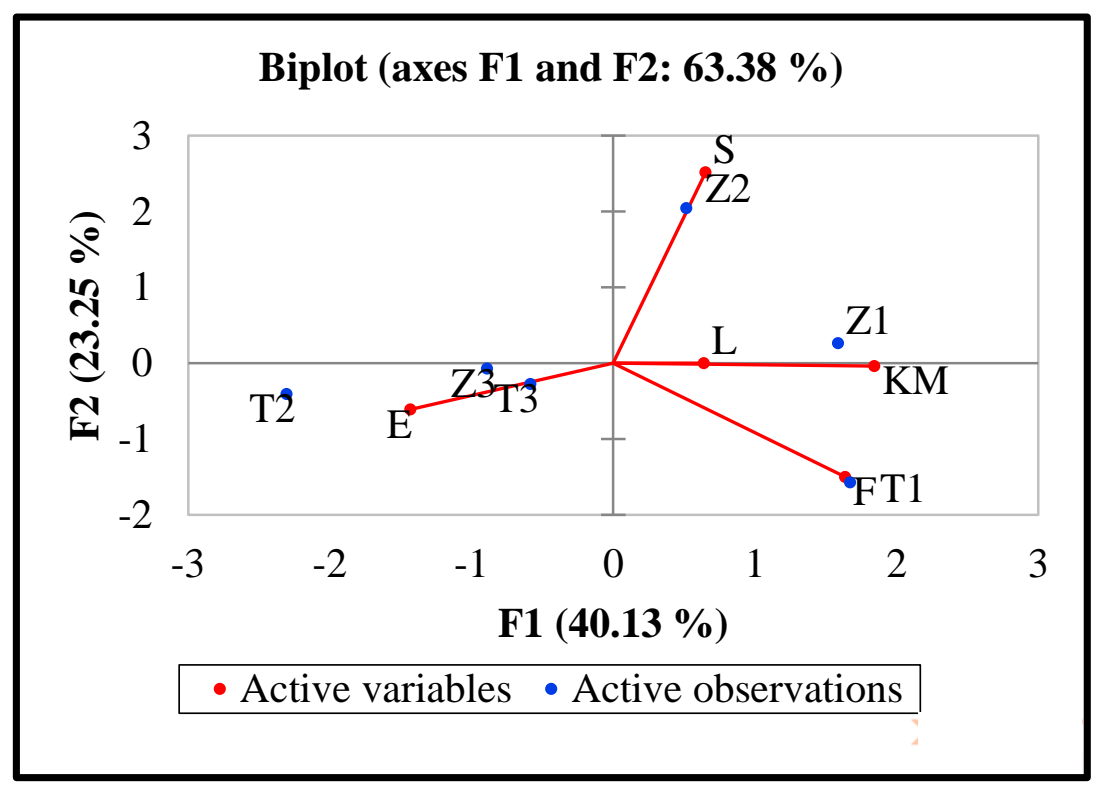

Figure 4. Principle Component Analysis (PCA) of oil distillated from parts of flowers, flower stalks and leaves of Tuni and Zanzibar clove varieties. Clove oil variable: oil content (OC), eugenol (E); plant variable: flower weight $(\mathrm{F})$, flower stalk weight $(\mathrm{S})$, leaf area (L).

The PCA generated two eigenvalues. The first PCA had a value of eigenvalues 2.01 with a variability of $40.13 \%$, the second had a value of eigenvalues 1.16 with variability of $23.25 \%$. Both eigenvalues illustrated data variations at 63.38 (\% cumulative/total variant). The PCA results show a relationship between clove oil and plant morphologies. The results obtained show that oil content was positively correlated with flower weight, meaning that the higher weight of the flower will be followed by the oil content increase. In contrast, flower weight and oil content showed a negative correlation with eugenol content. This means that the higher flower weight or oil content will not always be followed by an increase in eugenol levels. 


\section{DISCUSSION}

The distillation process of the flowers, flower stalks, and leaves from the two clove varieties was carried out by the steam-hydrodistilation method for 6 hours. The distillation result was the oil content at various water contents. The difference in water contents of the materials was determined by differences in material handling before the distillation process. The flowers and flower stalks before being distilled were dried beforehand, while the leaves were only withered. The results of the distillation showed that clove oil content of Zanzibar variety was slightly higher compared to the clove oil content of the Tuni variety in the whole distilled part. The difference in oil content obtained in both varieties is more determined by the characteristics of plant species (Figueiredo et al., 2008), in addition to other factors such as distilled plant organ parts, material particle size, and distillation duration (Figueiredo et al., 2008; Safrudin et al., 2015). The highest oil content of the two varieties was obtained in the flower section, then followed by flower stalks and the lowest was the leaves. The results of this study are in agreement with those obtained previously in cultivated cloves. Cultivated cloves produce the highest oil content in the flower part, which is around $10-20 \%$, then followed by flower stalks around 5-10\%, and the lowest is the leaves which is $<5 \%$ (Nurdjannah, 2004; Widayat et al., 2014; AtanasovaPancevska et al., 2017).

Clove oils produced from both varieties must be supported by quality based on the standard of clove oil. The clove oil standard was determined including color, weight, refractive index, solubility in $70 \%$ ethanol, total eugenol, and $\beta$ caryophyllene (BSN, 1996a, 2006). Clove oil colors produced from both varieties in the flower, flower stalks and leaves were still in the standard range of yellow to dark brown. The color of oil obtained from all parts analyzed from the two varieties was in accordance with those reported in previous studies on cultivated cloves (Farah et al., 2010). Widayat et al. (2014) and Alighiri et al. (2018) stated that the color of clove oil obtained from distillation was strongly influenced by several factors including the quality of the clove raw materials used and the distillation equipment used. The dark color of clove oil can be caused by accumulation of $\mathrm{Fe}$ ion due to inadequate equipment used.

The clove oil of Tuni and Zanzibar varieties from the whole distillation of flowers, flower stalks and leaves satisfied the standard parameters of specific gravity, refractive index, solubility in ethanol, total eugenol, but it was slightly higher in $\beta$-caryophyllene parameter for Tuni leaf oil and Zanzibar bud and leaf oils. The standardized specific gravity for bud oil is $1.04-1.07 \mathrm{~g} \mathrm{ml}^{-1}$ and for leaf oil is $1,025-1,049 \mathrm{~g} \mathrm{ml}^{-1}$. The required refractive index is $1.529-1.535$ for bud oil and 1.528-1.535 for leaf oil. The standard solubility in 70\% ethanol for bud oil and leaf oil is 1:2 clear. Total eugenol required is $80-90 \%$ for bud oil and $78 \%$ for leaf oil, whereas the $\beta$-caryophyllene parameter requires a maximum of $17 \%$ (BSN, 1996a, 2006). The physicochemical results of the clove oil from the two 
varieties as a whole show the quality standards of obtained clove oils. The quality of clove oil produced is determined by various factors including plant species and parts of plant organs analyzed. In addition, other factors such as particle size of materials, distillation methods and storage processes also influence the quality of oil produced (Figueiredo et al., 2008; Oreizi et al., 2014; Widayat et al., 2014; Safrudin et al., 2015).

PCA results showed that there is a relationship between clove oil and plant morphologies. The results showed that an increase in flower weight will be followed by an increase in oil content. For the whole part of the plant which was distilled, the highest oil content was obtained from the distillation of the flower parts of the two varieties. The cloves of Tuni and Zanzibar varieties are classified as cultivated cloves, which in average produce the highest oil content in the flower section (10-20\%) compared to the flower stalks and leaves (Nurdjannah, 2004; Hadi, 2012). Furthermore, the increase in oil is not always followed by an increase in eugenol. Eugenol is the main component of clove bud oil (70-96\%) where its content is strongly influenced by genetic, climate, soil, and cultivation techniques (Alma et al., 2007; Oreizi et al., 2014).

\section{CONCLUSION}

Tuni clove variety had a morphological size slightly larger than Zanzibar variety, but it had slightly lower oil content. The morphological organ part of the flower bud produced more oil content in both varieties followed by the flower stalks and the lowest was the leaves. Increasing flower weight and oil content was not always followed by an increase in eugenol content. The physicochemical properties of clove oil from all parts of flowers, flower stalks, and leaves of the Tuni and Zanzibar varieties of Ambon Island satisfied all the standards of clove oil, but it was slightly higher in the content of $\beta$-caryophyllene in leaf oils of both varieties.

\section{REFERENCES}

Alfian A., Mahulette, A.S., Zainal, M., Hardin, and Bahrun, A. 2019. Morphological character of raja clove (Syzygium aromaticum L . Merr \& Perry.) native from Ambon Island. IOP Conference Series: Earth and Environmental Science. 343(012150): 1-4. https://doi.org/10.1088/17551315/343/1/012150

Alighiri, D., Eden, W.T., Cahyono, E., and Supardi, K.I. 2018. Quality improvement by batch vacuum distillation and physicochemical characterization of clove leaf oil in Central Java, Indonesia. Journal of Physics: Conference Series. 983(012163). https://doi.org/10.1088/17426596/983/1/012163 
Alma, M.H., Ertaş, M., Nitz, S., and Kollmannsberger, H. 2007. Chemical composition and content of essential oil from the bud of cultivated Turkish clove (Syzygium aromaticum L.). BioResources. 2(2): 265-269.

Amini, F., Asghari, G.R., Talebi, S.M., Askary, M., and Shahbazi, M. 2016. Effect of environmental factors on the compounds of the essential oil of Lippia citriodora. Biologija. 62(3): 194-201. https://doi.org/10.6001/ biologija.v62i3.3372

Atanasova-Pancevska, N., Bogdanov, J., and Kungulovski, D. 2017. Antimicrobial activity and chemical composition of two essential oils and eugenol from flower buds of Eugenia caryophyllata. Open Biological Sciences Journal. 3(1): 16-25. https://doi.org/10.2174/235263350170301 0016

BSN. (1996a). SNI 06-4267-1996 tentang Minyak Bunga Cengkih. ICS71.100. 60.

BSN. (1996b). SNI 06-4374-1996 tentang Minyak Gagang Cengkih. ICS 71.100. 60.

BSN. (2006). SNI 06-2387-2006 tentang Minyak Daun Cengkih. ICS 71.100.60.

Daryono, E.D. 2015. Reactive extraction process in isolation of eugenol of clove essential oil (Syzigium aromaticum) based on temperature and time process. International Journal of ChemTech Research. 8(11): 564-569.

Farah, M.R., Da'i, M., and Munawaroh, R. 2010. Quality analysis of clove bud essential oils (Syzygium aromaticum (L.) Meer. \& Perry) from Maluku, Sumatera, Sulawesi and Java with metabolomic based on GC-MS method. Pharmacon. 11(2): 57-61.

Figueiredo, A.C., Barroso, J.G., Pedro, L.G., and Scheffer, J.J.C. 2008. Factors affecting secondary metabolite production in plants: volatile components and essential oils. Flavour and Fragrance Journal. 23(4): 213-226. https://doi.org/10.1002/ffj.1875

Hadi, S. 2012. Pengambilan minyak atsiri bunga cengkeh (clove oil) menggunakan pelarut n-heksana dan benzena. Jurnal Bahan Alam Terbarukan. 1(2): 25-30. https://doi.org/10.1152/ajpregu.00139.2015

IPGRI. (1980). Tropical Fruit Descriptor. Thailand: IPGRI-Southeast Asia Regional Committee.

Jentzsch, P.V., Gualpa, F., Ramos, L.A., and Ciobotă, V. 2017. Adulteration of clove essential oil: Detection using a handheld raman spectrometer. Flavour and Fragrance Journal. 33(2): 184-190. https://doi.org/10.1002/ ffj. 3438

Ketaren S. 1985. Pengantar Teknologi Minyak Atsiri. Jakarta (ID): Balai Pustaka. Mahulette, A.S., Hariyadi, Yahya, S., Wachjar, A., and Alfian, A. 2019a. Morphological traits of Maluku native forest clove (Syzygium aromaticum L. Merr \& Perry.). Journal of Tropical Crop Science. 6(2): 105-111. https://doi.org/10.29244/jtcs.6.02.105-111 
Mahulette, A.S, Hariyadi, Yahya, S., Wachjar, A., and Marzuki, I. 2019b. Morpho-agronomical diversity of forest clove in Moluccas, Indonesia. Hayati Journal of Biosciences. 26(4): 156-162. https://doi.org/10.4308/ hjb.26.4.156.

Mahulette, A.S., Hariyadi, Yahya, S., and Wachjar, A. 2019c. The physicochemical components and characteristic from essential oils of forest cloves Syzygium aromaticum (Myrtaceae) in Maluku Province, Indonesia. Plant Archives. 19(2): 466-472.

Maksimović, M., Vidic, D., Miloš, M., Sǒlić, M.E., Abadzić, S., and Siljak-Yakovlev, S. 2007. Effect of the environmental conditions on essential oil profile in two Dinaric Effect of the environmental conditions on essential oil profile in two Dinaric Salvia species: $S$. brachyodon Vandas and $S$. officinalis L. Biochemical Systematics and Ecology. 35: 473-478. https://doi.org/10.1016/j.bse.2007.02.005

Milind, P., and Deepa, K. 2011. Clove: A champion spice. International Journal of Research in Ayurveda \& Pharmacy. 2(21): 47-54.

[Ministry of Agriculture] Kementan. 2013. SK Kementan Nomor 4964/Kpts/ SR.120/12/2013. Tentang Pelepasan Cengkih Tuni Bursel, Sebagai Varietas Unggul. Jakarta.

Nejad, S.M., Özgüneş, H., and Başaran, N. 2017. Pharmacological and toxicological properties of eugenol. Turkish Journal Of Pharmaceutical Sciences. 14(2): 201-206. https://doi.org/10.4274/tjps.62207

Nurdjannah, N. 2004. Diversifikasi tanaman cengkih. Jurnal Perspektif. 3(2): 6170.

Oreizi, E., Rahiminejad, M.R., and Asghari, G. 2014. Influence of environment on glandular trichomes and composition of essential oil of Perovskia abrotanoides Karel. Jundishapur Journal of Natural Pharmaceutical Products. 9(4): 1-6. https://doi.org/10.17795/jjnpp-16432

Rathinam, P., and Viswanathan, P. 2018. Anti-virulence potential of eugenol-rich fraction of Syzygium aromaticum against multidrug resistant uropathogens isolated from catheterized patients. Avicenna Journal of Phytomedine. 8(5): 416-431.

Riyanto, Sastrohamidjojo, H., and Fariyatun, E. 2016. Synthesis of methyl eugenol from crude cloves leaf oil using acid and based chemicals reactions. IOSR Journal of Applied Chemistry. 9(10): 105-112. https://doi. org/10.9790/5736-091002105112

Safrudin, I., Maimulyanti, A., Prihadi, A.R., and Al, E. 2015. Effect of crushing of clove bud (Syzygium aromaticum) and distillation rate on main constituents of the essential oil. American Journal of Essential Oils and Natural Products. 2(3): 12-15. https://doi.org/10.1557/adv.2018.98 
Sohilait, H.J. 2015. Chemical composition of the essential oils in Eugenia caryophylata, Thunb from Amboina Island. Science Journal of Chemistry. 3(6): 95-99. https://doi.org/10.11648/j.sjc.20150306.13

Towaha, J. 2012. The benefits of cloves eugenol in various industries in Indonesia. Jurnal Perspektif. 11(2): 79-90.

Uddin, M.A., Shahinuzzaman, M., Sohel Rana, M., and Yaakob, Z. 2017. Study of chemical composition and medicinal properties of volatile oil from clove buds (Eugenia caryophyllus). International Journal of Pharmaceutical Sciences and Research. 8(2): 895-899. https://doi.org/10.13040/IJPSR097 5-8232.8(2).895-99

Widayat, Cahyono, B., Hadiyanto, and Ngadiwiyana. 2014. Improvement of clove oil quality by using adsorption-distillation process. Research Journal of Applied Sciences, Engineering and Technology. 7(18): 3867-3871. https://doi.org/10.19026/rjaset.7.744 